\title{
Chapter 17: \\ Utilising Kenya's marine resources for national development
}

Kariuki Muigua

1

Introduction

This chapter discusses how Kenya can maximise the use of its marine resources to spur economic growth and development for the betterment of its citizens' livelihoods. While it has been observed that oceans provide a substantial portion of the global population with food, livelihoods and are the means of transport for $80 \%$ of global trade, Kenya cannot arguably boast of securing as many benefits from its related resources. ${ }^{1}$ Furthermore, the marine and coastal environment also constitutes a key resource for the important global tourism industry, supporting all aspects of the tourism development cycle from infrastructure and the familiar 'sun, sand and sea' formula to the diverse and expanding domain of nature-based tourism. ${ }^{2}$ Tourism is one of Kenya's key economic sectors, but its potential has not been fully exploited. ${ }^{3}$ It has also been documented $^{4}$ that the seabed currently provides $32 \%$ of the global supply of hydrocarbons with exploration expanding and advancing technologies opening new frontiers of marine resource development from bio-prospecting to the mining of seabed mineral resources. The sea offers vast potential for renewable blue energy production from wind, wave, tidal, thermal and biomass sources. ${ }^{5}$ While Kenya has made some progress in this regard, it is yet to fully tap into these resources. This source of energy would be key in boosting Kenya's efforts towards meeting its energy requirements for national development and realising its Vision $2030 .^{6}$

The main livelihoods for the majority of Kenyans are agriculture, livestock, fishing and forestry. In addition, tourism is Kenya's greatest foreign exchange earner, and one of the largest sources of employment. ${ }^{7}$ The moist sub-humid to humid lands are classified as the high potential areas of Kenya, supporting rain-fed agriculture; while the

\footnotetext{
UN (2014); and Capital Business (2016).

UN (2014: 2).

Ruwa (2006).

UN (2014: 2).

Ibid.

Republic of Kenya (2014).

UNFAO \& Republic of Kenya (2006: 5).
} 
dry sub-humid lands have medium potential and are mainly used for agro-pastoralism. ${ }^{8}$ The rest of Kenya, which includes arid and semi-arid lands (ASAL), is suitable for pastoralism and wildlife and supports nearly half of the country's livestock population. ${ }^{9}$ In light of these variations in climatic conditions, Kenya needs to make use of all the natural resources within its territory to promote development. This includes the living and non-living marine resources in Kenya's territorial waters. This chapter discusses ways in which Kenya can take advantage of its location as a coastal state to fully exploit its marine resources for national development and to achieve sustainable livelihoods for its people.

The sovereign right of states to exploit natural resources lying within their territories is recognised in various international and regional legal instruments. This recognition, however, comes with responsibilities such as respecting the rights of other states to exploit their resources and the environmental obligation to take care of the various ecosystems.

The International Covenant on Civil and Political Rights provides that all people have the right of self-determination. By virtue of that right, they freely determine their political status and freely pursue their economic, social and cultural development. ${ }^{10}$ Furthermore, all people may freely dispose of their natural wealth and resources without prejudice to any obligations arising out of international economic cooperation, based upon the principle of mutual benefit and international law. In no case may a person be deprived of their own means of subsistence. ${ }^{11}$

The Protocol Against the Illegal Exploitation of Natural Resources (2006), ${ }^{12}$ concluded by the International Conference on the Great Lakes Region, has the following objectives: to promote and strengthen, in each member state, the development of effective mechanisms to prevent, curb and eradicate the illegal exploitation of natural resources; to intensify and revitalise cooperation among member states with a view to achieving more efficient and sustainable measures against the illegal exploitation of natural resources; and to promote the harmonisation by member states of their national legislations, policies and procedures against the illegal exploitation of natural

$8 \quad$ Ibid.

9 Ibid: 4.

10 Article I(1) of the International Covenant on Civil and Political Rights.

11 Article I(2) of the International Covenant on Civil and Political Rights.

12 Available at $<$ https://www.google.com/search?client=safari\&rls=en\&q=Protocol+Against + the+Illegal+Exploitation + of + Natural+Resources, $\&$ ie $=$ UTF-8\&oe=UTF-8\#> $($ accessed 30-72018). 
resources. ${ }^{13}$ Under this Protocol, the illegal exploitation of natural resources is considered a violation of the right of member states to permanent sovereignty over their natural resources, and contrary to the spirit and principles of the following international and regional instruments: ${ }^{14}$ the United Nations Charter; the Declaration on the Right to Development; the Constitutive Act of the African Union; and the African Charter on Human and Peoples' Rights.

The fundamental principle of the African Convention on the Conservation of Nature and Natural Resources is that contracting states should undertake to adopt measures necessary to ensure the conservation, use and development of soil, water, flora and faunal resources in accordance with scientific principles and with due regard to the best interests of the people. ${ }^{15}$

The principles of sovereignty and the right to exploit natural resources within a state's jurisdiction govern the use of resources falling within their marine territories. Unless countries allow other states or foreigners to exploit such resources through licensing, the international law regime prohibits such affront to the sovereignty of an independent state.

Article 55 of the United Nations Convention on the Law of the Sea (UNCLOS) defines the exclusive economic zone (EEZ) as an area beyond and adjacent to the territorial sea, subject to the specific legal regime established in this part, under which the rights and jurisdiction of the coastal state and the rights and freedoms of other states are governed by the relevant provisions of this Convention. Article 56 further provides for the rights, jurisdiction and duties of the coastal state in the EEZ. Specifically, it provides that in the EEZ, the coastal state has: ${ }^{16}$

- $\quad$ sovereign rights for the purpose of exploring and exploiting, conserving and managing the natural resources, whether living or non-living, of the waters superjacent to the seabed and of the seabed and its subsoil, and with regard to other activities for the economic exploitation and exploration of the zone, such as the production of energy from the water, currents and winds;

- jurisdiction as provided for in the relevant provisions of the Convention with regard to the establishment and use of artificial islands, installations and

13 Article 2 of the Protocol on the Illegal Exploitation of Natural Resources.

14 Article 4 of the Protocol on the Illegal Exploitation of Natural Resources.

15 Article 2 of the African Convention on the Conservation of Nature and Natural Resources (1968).

16 Article 56(1) of UNCLOS. 
structures; marine scientific research; the protection and preservation of the marine environment; and

- other rights and duties provided for in the Convention.

However, in exercising its rights and performing its duties in the EEZ, the coastal state should have due regard to the rights and duties of other states and should act in a manner compatible with the provisions of the Convention. ${ }^{17}$ The rights relating to the seabed and subsoil should also be exercised in accordance with the provisions contained in Part VI. ${ }^{18}$

Article 76(1) of the UNCLOS defines the continental shelf of a coastal state as comprising the sea-bed and subsoil of the submarine areas that extend beyond its territorial sea throughout the natural prolongation of its land territory to the outer edge of the continental margin, or to a distance of 200 nautical miles from the baselines from which the breadth of the territorial sea is measured where the outer edge of the continental margin does not extend up to that distance.

These provisions apply to Kenya, which is a coastal state located on the eastern coast of the African Continent, between latitudes $5^{\circ} 4^{\prime} \mathrm{S}$ north and $4^{\circ} 40^{\prime} \mathrm{S}$ and between longitudes $33^{\circ} 50^{\prime} \mathrm{E}$ and $41^{\circ} 45^{\prime} \mathrm{E}$. It has a total land surface area of $582,644 \mathrm{~km}^{219}$ and a coastline of about $640 \mathrm{~km}$ extending from latitudes $1^{\circ} 41^{\prime} \mathrm{S}$ to $4^{\circ} 30^{\prime} \mathrm{S}$ and forming part of the western border of the Indian Ocean marine eco-region. ${ }^{20}$

Kenya's Maritime Zones Act (1989) was enacted to consolidate the law relating to Kenya's territorial waters and the continental shelf. It provides for: ${ }^{21}$

- the establishment of the EEZ of Kenya;

- the exploration and exploitation and conservation and management of the resources of the maritime zones; and

- other connected purposes.

Section 4 of the Maritime Zones Act establishes and defines Kenya's EEZ. ${ }^{22}$ It is noteworthy that Section 5 of the Act provides that:

Kenya shall, within the exclusive economic zone, exercise sovereign rights with respect to the exploration and exploitation and conservation and management of the natural resources of the zone and without prejudice to the generality of the foregoing, the exercise of the sovereign rights shall be in respect of -

(a) exploration and exploitation of the zone for the production of energy from the tides, water currents and winds;

(b) regulation, control and preservation of the marine environment;

17 Article 56(2) of UNCLOS.

18 Article 56(3) of UNCLOS. Part VI has provisions dealing with the continental shelf.

19 UNFAO \& Republic of Kenya (2009: 13).

20 Anam \& Mostarda (2012).

21 Preamble of the Maritime Zones Act (1989).

22 Section 4 of the Maritime Zones Act (1989). 
(c) establishment and use of artificial islands and offshore terminals, installations, structures and other devices; and

(d) authorisation and control of scientific research.

The First Schedule to the Act describes Kenya's territorial waters. The foregoing provisions define the area within which Kenya should be seeking to exploit resources to spur the growth and development of its economy. However, this may not be entirely possible at the moment due to a number of challenges. The Kenyan marine habitats support a wide variety of species, most of which are harvested by artisanal fishers operating mostly between the shoreline and the reef. ${ }^{23}$ It is estimated that the annual economic value of goods and services in the marine and coastal ecosystem in the blue economy in the western Indian Ocean today is a little over \$22 billion, with Kenya's share being slightly over $\$ 4.4$ billion and the tourism sector taking the lion share at over $\$ 4.1$ billion. $^{24}$

The 1985 Nairobi Convention for the Protection, Management and Development of the Marine and Coastal Environment of the Eastern African Region (Nairobi Convention) requires state parties, including Kenya, to take all appropriate measures to prevent, reduce and combat pollution of the convention area (Article 4), particularly pollution from ships (Article 5), dumping (Article 6), land-based sources (Article 7), exploration and exploitation of the seabed (Article 8), and airborne pollution (Article 9). States parties undertake to protect and preserve rare or fragile ecosystems as well as the habitat of depleted, threatened or endangered species and other marine life in specially protected areas (Article 10); and to cooperate in dealing with pollution emergencies in the convention area (Article 11). Article 12 also requires parties to take all appropriate measures to prevent, reduce and combat environmental damage resulting from dredging, land reclamation, and other engineering activities in the convention area. Moreover, they are to develop guidelines for the planning of major development projects in the convention area, assess the environmental effects of development projects likely to cause significant adverse changes in the convention area and develop procedures for dissemination of information and consultation among the parties in such assessments. ${ }^{25}$ Parties are also encouraged to cooperate in scientific research and monitoring in the convention area, to exchange collected data ${ }^{26}$ and to develop rules and procedures to govern liability and compensation for damage caused by pollution in the convention area. ${ }^{27}$ The Nairobi Convention spells out more practical obligations for coastal states in the East African coastal region that can go a long way in boosting the conservation and exploitation of the resources within this region. 
This chapter covers both the living and non-living resources lying within Kenya's marine territory. While it may highlight rights of other actors as provided for under Article 56(1), the main focus is on Kenya's sovereign rights to explore and exploit, conserve and manage living or non-living natural resources in the waters superjacent to the seabed and of the seabed and its subsoil. It also addresses other activities relating to the economic exploitation and exploration of the zone, such as the production of energy from the water, currents and winds.

The blue economy concept is generally used to cover both aquatic and marine spaces, including oceans, seas, coasts, lakes, rivers and underground water. It encompasses a range of productive sectors, including fisheries, aquaculture, tourism, transport, shipbuilding, energy, bioprospecting and underwater mining. ${ }^{28}$ A United Nations Blue Economy Concept Paper $^{29}$ captures the importance of the blue economy in national development. It acknowledges that the coastal and island developing countries have remained at the forefront of the blue economy advocacy, recognising that the oceans have a major role to play in humanity's future; and that the blue economy offers an approach to sustainable development that is better suited to their circumstances, constraints and challenges. ${ }^{30}$ It also highlights the fact that cutting-edge technologies and rising commodity prices are opening up new realms of opportunity for submarine exploitation; that the high seas constitute the last global commons; and urgent attention is required to enable the sound management of ocean resources to realise sustainable development. ${ }^{31}$

Investing in the long-term health of coastal and marine resources is vital to the sustainability of the global economy. This is because oceans provide economic wealth from minerals, fisheries, transport and numerous other uses for food security and national development. ${ }^{32}$ Investment in the sector is therefore needed to take advantage of the opportunities offered by the blue economy. However, many of the ocean habitats are deteriorating, species in them are threatened with extinction, their chemical nature is changing due to pollution and ocean acidification, and much of their value and that of coastal ecosystems has been lost due to poor management and overuse. ${ }^{33}$ Conservation of the environment should therefore be an integral part of resource exploitation.

\footnotetext{
28 UNECA (2016: 1).

29 UN (2014: 2).

30 Ibid.

31 Ibid

32 Svensson \& Pendleton (2014: 25).

33 Ibid: 5.
} 
Offshore oil and gas production pose some of the greatest risks to the sustainable development agenda due to potential pollution. Countries seeking to explore offshore oil and gas production need to invest heavily in the sector and develop capacity to ensure that while they benefit from the resultant products, the environmental concerns are fully addressed. The next section of this chapter highlights the challenges facing Kenya in managing its EEZ and the exploitation of the resources lying therein.

\section{$5 \quad$ Kenya's marine resources and exploitation challenges}

Kenya has a rich diversity of marine and coastal ecosystems, which include mangrove wetlands, coastal forests, estuaries, sandy beaches, sand dunes, coral reefs and seagrass beds that support a host of marine and coastal species. ${ }^{34}$ With the exception of mangrove swamps, which have been studied in detail, there is currently limited taxonomical information on the marine biota of Kenya, and species lists for coastal and pelagic environments are incomplete. ${ }^{35}$ There are twelve patches of mangrove forests along the Kenya coast, with an estimated total area of between 53,000 and 61,000 ha, with $67 \%$ occurring in the Lamu district and $10 \%$ each in the Kilifi and Kwale Districts. ${ }^{36}$ Mangrove forests are nutrient-rich environments supporting a variety of food chains and functioning as a nursery and feeding ground for fish and invertebrates. Many of these species spend part of their life cycle in coral reefs, seagrasses and open waters. Mangrove trees are also important for shoreline stabilisation and provide resources for both rural and urban coastal populations. ${ }^{37}$

Kenya enjoys a reputation as one of the world's great big game sports fishing destinations. ${ }^{38}$ Its marine waters contain most of the major target game species, including billfishes, sailfish, swordfishes, marlins, sharks and some tunas. ${ }^{39}$ Sports fishers are registered in several sport-fishing clubs, which coordinate fishing activity and record data. ${ }^{40}$ The peak sports fishing season is from September to March, and the popular sport-fishing areas are Malindi, Watamu, Shimoni and Lamu. ${ }^{41}$ In 2005, 30 sport-fishing clubs were registered. ${ }^{42}$

The marine fisheries are classified into two subsectors: the coastal artisanal fishery; and the EEZ fishery. ${ }^{43} \mathrm{~A}$ basic feature of the coastal fishery is the largely subsistence

$\begin{array}{ll}34 & \text { Tuda \& Omar (2012: 43). } \\ 35 & \text { Anam \& Mostarda (2012: 1). } \\ 36 & \text { Ibid: } 3 . \\ 37 & \text { Ibid. } \\ 38 & \text { Ibid. } \\ 39 & \text { Ibid. } \\ 40 & \text { Ibid: } 4 . \\ 41 & \text { Ibid. } \\ 42 & \text { Ibid. } \\ 43 & \text { UNFAO (2016). }\end{array}$


and artisanal nature of the fishers who operate small craft propelled by wind sails and manual paddles. ${ }^{44}$ The EEZ fishery, on the other hand, is characterised by distant-water fishing vessels which exploit target species mainly with purse-seines and long-lines. ${ }^{45}$ It is also estimated that the maximum sustainable yield of Kenya's marine and coastal waters is between 150,000 and 300,000 metric tonnes, while the current production level is only about 9,000 metric tonnes per annum. ${ }^{46}$

Most fishing in Kenya is artisanal, with a little industrial fishing by prawn trawlers. It is estimated that approximately $80 \%$ of the total marine products come from shallow coastal waters and reefs, while only $20 \%$ are from off-shore fishing. ${ }^{47}$ Distant Waters Fishing Nations (DWFN) currently fish in the EEZ through a licensing system, and only a small quantity of catch from the EEZ is landed in Kenya, primarily tuna for export. ${ }^{48}$ The local fishers lack the capacity to exploit deep water resources. Overfishing in inshore areas has continued to cause a decline in fish catches, while the deeper territorial waters remain underexploited. ${ }^{49}$

As for the mineral resources within the territorial waters of the country, these remain largely untapped, due to technological challenges. However, it is noteworthy that the Kenyan territorial waters also fall under the exploration blocks allocated to foreign companies licensed to carry out oil and mineral exploration in the country. For instance, from August 2014, there has been an ongoing boundary dispute before the International Court of Justice (ICJ) between the Republic of Kenya and the Federal Republic of Somalia regarding maritime delimitation in the Indian Ocean. ${ }^{50}$ Somalia contends that both states "disagree about the location of the maritime boundary in the area where their maritime entitlements overlap", and asserts that "[d]iplomatic negotiations, in which their respective views have been fully exchanged, have failed to resolve this disagreement". ${ }^{51}$ Somalia requested the Court: ${ }^{52}$

to determine, on the basis of international law, the complete course of the single maritime boundary dividing all the maritime areas appertaining to Somalia and to Kenya in the Indian Ocean, including the continental shelf beyond 200 [nautical miles].

Somalia further asked the Court "to determine the precise geographical coordinates of the single maritime boundary in the Indian Ocean". ${ }^{53}$ It is arguable that the main reason

44 Ibid

45 Ibid.

46 Ibid

47 Fondo (2004: 6).

48 Ibid.

49 Anam \& Mostarda (2012: 3).

50 See $<$ http://www.icj-cij.org/docket/files/161/18360.pdf $>$ (accessed 12-5-2017).

51 International Court of Justice, Dispute Concerning Maritime Delimitation in the Indian Ocean (Somalia v. Kenya) (2014) para. 17.

52 Ibid: paras 36 and 37.

53 Ibid. 
for disputes such as this one is the vast resources found in these areas. ${ }^{54}$ This may be supported by the fact that Kenya has already awarded some of its petroleum blocks in the disputed area to potential investors for oil prospecting. The outcome of this dispute will have an impact on the exploration and exploitation of the marine resources lying in the contested areas.

Kenya has been a party to UNCLOS since March 1989 and to the 1995 UN Fish Stocks Agreement since July 2004. Kenya also signed the Port State Measures Agreement in November 2010, is a member of the Committee for Inland Fisheries of Africa (CIFA), a founding member of Aquaculture Network for Africa (ANAF), a member of the FAO Indian Ocean Tuna Commission (IOTC), and a member of the FAO South West Indian Ocean Commission for Fisheries (SWIOFC). These bodies generally advocate for sustainable management and exploration of marine resources for development, conservation and protection.

It is estimated that the fisheries sector presently accounts for approximately $0.5 \%$ of Kenya's gross domestic product (GDP), where revenues from inland fisheries make up $95 \%$ of this contribution and marine fisheries only $5 \% .{ }^{55}$ Kenya can take full advantage of its diverse marine resources in order to boost the livelihoods of the coastal area's communities as well as the overall national income. There is, however, a need to adopt or strengthen a number of approaches to the management and exploitation of marine resources for this to be achieved.

\subsection{Adopting an integrated coastal zone management approach to promote effective co-management}

Integrated coastal zone management (ICZM) has been described as a dynamic, multidisciplinary and iterative process to promote the sustainable management of coastal zones. It is one of the integrated marine and coastal area management approaches that cover the full cycle of information collection, planning (in its broadest sense), decision making, management and implementation monitoring. ICZM uses the informed participation and cooperation of all stakeholders to assess the societal goals in a given coastal area and to take actions toward meeting these objectives. ICZM seeks, over the long-term, to balance environmental, economic, social, cultural and recreational objectives, all within the limits set by natural dynamics. 'Integrated' in ICZM refers to 
the integration of objectives and also to the integration of the many instruments needed to meet these objectives. It means integration of all relevant policy areas, sectors and levels of administration. It means integration of the terrestrial and marine components of the target territory in both time and space. ${ }^{56}$

Integrated management has also been described as $--^{57}$

an approach that provides policy direction and a process for defining objectives and priorities, and planning development beyond sectoral activities. This is because it adopts a systems perspective and multi-sectoral approach which takes into account all sectoral interests and stakeholder interests, and deals with economic and social issues as well as environmental and ecological issues ... by employing a holistic, ecosystem perspective recognising the interconnections between coastal systems and uses, ICZM avoids traditional sectoral management approaches.

While it is true that Kenya has already adopted ICZM in the management of various environmental issues ${ }^{58}$ there is need to not only fully exploit the resources but also to actively and meaningfully involve communities in ICZM implementation. It has rightly been argued that the great diversity of ecosystems and species situated along the Kenyan coastline and the widespread dependence of communities on these natural resources, require that attention be paid to promoting the sustainable use of these natural resources. ${ }^{59}$ Proponents of the full and active implementation of ICZM argue that it would go a long way to promoting such sustainable use if it dealt with problems such as: the modification of habitats/ecosystems that results in reduced capacity to meet basic human needs (food, fuel, shelter) for the local communities; loss of cultural heritage; loss of existing income and foreign exchange, and high costs of restoring modified ecosystems; overexploitation of fisheries and other living resources that causes reduced economic returns and threatens inter-generational equity; microbiological pollution, beach erosion and siltation of the inshore lagoon waters causing increased costs of shoreline protection, increased water treatment costs, as well as problems in the tourism business; and biodiversity loss, collapse of cultural values and poverty. ${ }^{60}$

Kenya's marine protected areas (MPAs) are considered essential components of an ICZM program because they protect biodiversity and ecological processes on which humans residing in the coastal zone depend. ${ }^{61}$ There is a need for the meaningful inclusion and the active participation of coastal communities in the conservation and exploitation of marine resources to realise enhanced conservation and productivity from these resources. For instance, while MPAs can benefit local communities through empowerment, improved governance, alternative livelihoods, improved fisheries, and social, educational, and cultural benefits; ${ }^{62}$ it has been argued that they can also be

European Commission (1999).

57 Meltzer (1998: 9).

58 Republic of Kenya (2013).

59 Ochiewo (2001: 1).

60 Ibid: 3. See also generally, Clark (1992: 167).

61 Tuda \& Omar (2012: 45).

62 Bennetta \& Dearden (2014). 
used to deny local communities means of livelihood, where it is reported that due to the high number of MPAs already in place in the Kenyan coastal area, there is resistance from fishers to the introduction of additional protected areas. ${ }^{63}$ It is suggested that good governance is promoted through legitimacy, transparency, accountability, inclusiveness or participation, fairness or equity, integration or coordination, capability and adaptability. ${ }^{64}$ As such, an effective MPA management requires adequate capacity and resources, effective communication of rules and regulations (such as boundaries), extensive programs of education and outreach, participatory processes to create management structures, consideration of the values of all stakeholders, relationships built on trust, coordination with other management institutions, integration of scientific and traditional knowledge, and mechanisms for conflict resolution and to ensure transparency and accountability. ${ }^{65}$

The Fisheries (Beach Management Units) Regulations (2007) establish the Beach Management Units (BMUs) whose objectives include to: support the sustainable development of the fisheries sector; help alleviate poverty and to improve the welfare and livelihoods of members through improved planning and resource management, good governance, democratic participation and self-reliance; strengthen the management of fish-landing stations, fishery resources and the aquatic environment; recognise the various roles played by different sections of the community including women in the fisheries sector; and to prevent or reduce conflicts in the fisheries sector. ${ }^{66}$ BMUs are also part of efforts to promote fisheries co-management in Kenya. Past research ${ }^{67}$ on the operation of BMUs has indicated that they have not been operating efficiently and optimally. It has been recommended that to improve performance, there is a need to: expand and strengthen existing BMU financial and technical resource bases; register BMUs as fisheries co-management institutions; confer fishing rights through a comanagement policy; secure land for BMU infrastructural development; improve fish production, marketing and distribution channels; and improve post-harvest practices and technologies through training and provision of appropriate equipment. ${ }^{68}$

6.2 Investing in science and technology for marine resource exploration and exploitation

As already pointed out, much of the artisanal fishing and exploitation of marine resources along the Kenyan coast happens within the shallow waters of Kenya's

63 Fondo (2004: 8).

64 Bennetta \& Dearden (2014).

65 Ibid.

66 Regulation 3(3) of the Fisheries (Beach Management Units) Regulations (2007).

67 Kanyange et al. (2014).

68 Ibid. 
territorial waters. This means that there are still deep-sea resources within the country's national jurisdiction that are yet to be exploited for the benefit of the Kenyan coastal communities and the country at large.

The offshore fisheries zone is mainly exploited by licensed fishing DWFN vessels targeting highly migratory tuna species in the Kenyan EEZ, with no obligations to land, trans-ship or declare catches in the country. ${ }^{69}$ This arrangement limits the country's benefits derived from its EEZ fisheries, especially from value addition activities associated with trans-shipment, landing for processing or even from trade in by-catch. This situation is attributable to the fact that there are no local fishing fleets and or locally-based foreign fishing fleets targeting these offshore resources. ${ }^{70}$

There is need to invest in science and technology as a means of enhancing management of marine resources in Kenya, and to enable local communities, in general, to access marine resources currently unavailable to them due to technological challenges.

It is also suggested that in the context of a blue economy, higher fish production with lower environmental damage is possible through polyculture, species diversification, optimal feeds and feeding, prevention of diseases and countries embracing the blue economy focusing more on developing sophisticated technologies for farming, conservation and processing of species. ${ }^{71}$ The role of small-scale aquaculture by native fishing communities is also considered paramount from the perspective of food security and boosting their livelihood by selling surplus fish in the urban markets. ${ }^{72}$ Furthermore, it is suggested that by having enabling policies on pricing, certification, labelling and marketing, the fishing sector in the context of the blue economy can be more organised and regulated. ${ }^{73}$

There is also a need for the state to equip artisanal fishermen with more advanced fishing vessels through providing grants and loans to them to purchase or hire these advanced vessels. They should also be equipped with knowledge on sustainable fishing practices and environmental conservation to ensure the exploitation of the marine resources on a sustainable basis. Investing in science and technology for the preservation of harvested marine resources for longer and safer storage for marketing will also help the fishing communities to minimise losses, increase their profit margin, and enhance food security locally and nationally.

$69 \operatorname{KCDP}(2013: 9)$.

70 Ibid.

71 Mohanty et al. (2015: 11).

72 Ibid.

73 Ibid. 


\subsection{Regulating foreign vessels in Kenya's deep seas and high seas territories}

It has been observed that due to the nature of the high seas activities, supervision of the fishing area is a big problem and it is likely that unlicensed fishing vessels could easily poach fish from Kenyan territorial waters. It is also difficult to get accurate information about the fish caught by foreign-owned vessels. ${ }^{74}$ There is therefore a need to enforce the fishing regulations governing such activities in order to ensure that the country does not lose its resources and foreign exchange revenue derived from these resources.

Illegal, unregulated and unreported (IUU) fishing is identified as one of the major challenges facing developing countries due to inadequate or total lack of relevant technological capacity. The fight against IUU fishing activities has even gained international attention in the international fisheries management agenda. ${ }^{75}$

\subsection{Ecosystem-based approach to marine resources management}

The ecosystem approach in the context of marine resource management has been defined as: ${ }^{76}$

the comprehensive integrated management of human activities based on the best available scientific knowledge about the ecosystem and its dynamics, in order to identify and take action on influences which are critical to the health of marine ecosystems, thereby achieving sustainable use of goods and services and maintenance of ecosystem integrity.

The ecosystem approach has been heralded as a key framework for delivering sustainable development in both the terrestrial and the coastal and marine environment, as it provides an important framework for assessing biodiversity and ecosystem services, and evaluating and implementing potential responses. ${ }^{77}$ Ecosystem-based management is seen as a place - or area -focusing on a specific ecosystem and the range of activities affecting it. It implies that after a certain area has been defined, sustainable development and use will be established for all activities in the whole area. ${ }^{78}$ In addition, its application involves a focus on the functional relationships and processes within ecosystems, attention to the distribution of benefits that flow from ecosystem services, the use of adaptive management practices, the need to carry out management actions at multiple scales, and inter-sectoral cooperation..$^{79}$ There is a need to make this approach

74 Fondo (2004: 6).

75 Le Gallic \& Cox (2006); and Agnew et al. (2009).

76 Douvere \& Ehler (2009: 78).

77 Douvere (2008: 764).

78 Ibid.

79 Ibid. See also Port \& Indian Ocean Commission (1997). 
fully operational in Kenya in order to attain the goals of sustainability ensure that all stakeholders get to participate and benefit from the use of marine resources.

\subsection{Capacity-building for stakeholders}

It is noteworthy that the efficiency of Kenya's fisheries and marine sector is dependent on the institutions and the stakeholders behind it. While there are a number of statecontrolled management institutions driving the sector, there is a need to ensure that they are led by people who are competent and knowledgeable as far as implementation of the existing framework is concerned. The capacity of institutions such as the Kenya Marine and Fisheries Research Institute (KMFRI) ${ }^{80}$ and the State Department for Fisheries and the Blue Economy ${ }^{81}$ should be enhanced. They should be well equipped not only to enable them to carry out their mandates more efficiently, but also to reach out and cooperate more effectively with all other stakeholders in the sector.

One of the recognised principles of the ecosystem approach to management is that it should consider all forms of relevant information, including scientific, indigenous and local knowledge, innovations and practices. ${ }^{82}$ It is therefore imperative to build the capacity of stakeholders to effectively participate in the implementation of the ecosystem approach.

\subsubsection{Human resource capacity development}

There is a need to ensure that there is a synergy between the various institutions, especially if management responsibilities are decentralised. One of the ways that cooperation can be achieved is through the development and adoption of mechanisms for integrated planning. There is also a need for human resource development through training of administrative staff, observers on board fishing vessels, enforcement officers,

80 Kenya Marine and Fisheries Research Institute (KMFRI), a State Corporation under the Ministry of Agriculture, Livestock and Fisheries, has a mandate to undertake research in marine and freshwater fisheries, aquaculture, environmental and ecological studies, in order to provide scientific data and information for sustainable exploitation, management and conservation of Kenya's fisheries resources, and contribute to national strategies of food security, poverty alleviation, clean environment and creation of employment as provided for under vision 2030. See $<$ http://www.kmfri.co.ke/index.php/careers/vacancies> (accessed 10-6-2017).

81 The State Department for Fisheries and the Blue Economy was created by Executive Order No. 1/2016 under the Ministry of Agriculture Livestock and Fisheries. It is mandated to facilitate the exploration, exploitation, utilisation,management, development and conservation of fisheries resources as well as aquaculture development and to undertake research in marine and freshwater fisheries, see <http://www.kilimo.go.ke/fisheries/index.php/about-us/mandate/> (accessed 10-6-2017).

82 AID Environment \& National Institute for Coastal and Marine Management (2004: 5). 
scientists and advisers, and fishers, to optimise their interaction in the participatory processes.

Sustainable development also requires establishing functional interconnections between administrations dealing with fisheries and the environment within the ecosystem boundaries.

\subsubsection{Effective framework for negotiations involving multiple stakeholders}

As a way of achieving sustainable management of resources, equitable benefit sharing and the effective management of potential conflicts, there is a need to establish an effective framework for conducting negotiations between multiple stakeholders. This will not only be useful in achieving the principles of participation and transparency, but will also ensure that all the relevant stakeholders collectively participate in the management of marine and fisheries resources along Kenya's coastline. Ultimately, this will promote social and economic development within the confines of the principles of sustainable development.

\subsubsection{Scientific research capacity development}

It has been suggested that ways of improving efficiency and productivity in the marine and fisheries sector include: strengthening research; improving data collection, integrated analysis and communication; developing a better understanding of the ecosystem's functioning; evaluating policy and management options; identifying trade-offs; ensuring the use of appropriate assessment methodologies (including management performance and risk assessment); and identifying relevant indicators and reference points. ${ }^{83}$ Well-functioning information systems are important to support indicators for different fisheries and ecosystems, including large-scale multi-criteria descriptions of ecosystems such as GIS. ${ }^{84}$

\section{Conclusion}

Coastal areas throughout the world are under stress, with various anthropogenic factors such as population growth, pollution, habitat degradation, multiple resource use conflicts, and over-exploitation of resources causing marine environmental degradation

83 Garcia \& Cochrane (2005: 315).

84 Ibid. 
and depletion of coastal resources. ${ }^{85}$ Marine resources, especially along Kenya's coast hold great potential to contribute to national development. However, for this to be a reality, the foregoing anthropogenic factors ought to be addressed. Notably, some of these factors such as population growth, multiple resource use conflicts and over-exploitation of the resources can most effectively be addressed through the adoption of more efficient management approaches. Some of the approaches suggested in this chapter could go a long way in achieving this since they bring all stakeholders on board in their mode of operation. They are also likely to gain the acceptance and credibility that can only come with addressing the interests and concerns of all, while at the same time achieving sustainability. Kenya's economic blueprint, Vision 2030, requires the mobilisation of all national resources for sustainable national development. It is therefore important that measures are put in place to maximise the benefits accruing from Kenya's coastal marine and fisheries sector to boost social and economic development. As part of its efforts to realise Vision 2030, Kenya should fully utilise its marine resources to improve the livelihoods of its people and to boost the national economy generally.

\section{References}

Agnew, DJ, J Pearce, G Pramod, T Peatman, R Watson, JR Beddington \& TJ Pitcher (2009) "Estimating the worldwide extent of illegal fishing" 4(2) Plos one e4570, at <http://journals.plos.org/plosone/article/file?id=10.1371/journal.pone.0004570\&type=printable $>\quad$ (accessed 3-8-2018).

AIDEnvironment \& National Institute for Coastal and Marine Management (2004) Integrated marine and coastal area management (imcam) approaches for implementing the Convention on Biological Diversity CBD Technical Series No. 14, at $<$ https://www.cbd.int/doc/publications/cbd-ts14.pdf $>$ (accessed 10-6-2017).

Anam, R \& E Mostarda (2012) Field identification guide to the living marine resources of Kenya, FAO Species Identification Guide for Fishery Purposes.

Bennetta, NJ \& P Dearden (2014) "Why local people do not support conservation: community perceptions of marine protected area livelihood impacts, governance and management in Thailand" 44 Marine Policy 107-116.

Capital Business (2016) "Let's expand fishing in Indian Ocean, President urges coastal counties" Capital Business (1-9-2016), at <http://www.capitalfm.co.ke/business/2016/09/lets-expand-fishing-indian-ocean-president-urges-coastal-counties/ (accessed 1-4-2016).

Clark, JR (1992) Integrated management of coastal zones FAO Fisheries Technical Paper No. 327, at $<\mathrm{http}$ //campusdomar.es/observatorio/_documentos/ordenacion_del_litoral/doctrina/integrated_management_of_coastal_zones.pdf $>$ (accessed 12-5-2017).

Douvere, F (2008) “The importance of marine spatial planning in advancing ecosystem-based sea use management" 32(5) Marine Policy 762-771. 
Douvere, F \& CN Ehler (2009) "New perspectives on sea use management: initial findings from European experience with marine spatial planning" 90 Journal of Environmental Management 7788.

European Commission (1999) Towards a European Integrated Coastal Zone Management (ICZM) Strategy: general principles and policy options.

Farah, H (2015) "Why Somalia has to withdraw case against Kenya at the ICJ?" Horseed Media (317-2015), at <https://horseedmedia.net/2015/07/31/why-somalia-has-to-withdraw-case-againstkenya-at-the-icj/> (accessed 12-5-2017).

Fondo, EN (2004) Assessment of the Kenyan marine fisheries from selected fishing areas, at $<$ http://www.unuftp.is/static/fellows/document/estherprf04.pdf $>$ (accessed 14-5-2017).

Freight Logistics (2018) “Major boost for 'blue economy' as Kenya hosts global maritime conference" (24-2-2018), at <http://feaffa.com/magazine/2018/02/24/major-boost-for-blue-economyas-kenya-hosts-global-maritime-conference/> (accessed 8-5-2018).

Garcia, SM \& KL Cochrane (2005) "Ecosystem approach to fisheries: a review of implementation guidelines" 62(3) ICES Journal of Marine Science: Journal du Conseil 311-318.

Kanyange N, P Kimani, P Onyango, S Sweenarain \& Y Yvergniaux (2014) Performance assessment of beach management units along the coastlines of Kenya and Tanzania, at $<\mathrm{www}$.fao.org/3/aaz413e.pdf $>$ (accessed 1205-2017).

KCDP / Kenya Coastal Development Project (2013) Draft monitoring, control and surveillance (MCS) standard operating procedures (SOPs) for the marine and coastal fisheries of Kenya, at $<$ http://www.kcdp.co.ke/en/reports/project-documents/draft-monitoring-control-and-surveillance-mcs-standard-operating-procedures-sops $>$ (accessed 12-5-2017).

Le Gallic, B \& A Cox (2006) “An economic analysis of illegal, unreported and unregulated (IUU) fishing: key drivers and possible solutions" 30(6) Marine Policy 689-695.

Meltzer, E (1998) International review of integrated coastal zone management, at $<\mathrm{http}: /$ www.dfompo.gc.ca/Library/253987.pdf> (accessed 12-5-2017).

Mohanty, SK, P Dash, A Gupta \& P Gaur (2015) Prospects of blue economy in the Indian Ocean, at $<$ http://www.ris.org.in/sites/default/files/Final_Blue_Economy_Report_2015-Website.pdf $>$ (accessed 3-8-2018).

Ochiewo, J (2001) The Kenyan coastal and marine resources management: a case study of the socioeconomic setting of Mida Creek Proceedings of the 12th Biennial Coastal Zone Conference Cleveland 15-19 July 2001, at <http://webapp1.dlib.indiana.edu/virtual_disk_library/index.cgi/ 4916229/FID3790/pdf_files/ochiewoj.pdf> (accessed 14-5-2017).

Port \& Indian Ocean Commission (1997) Integrated coastal area management: the role of the regional environment programme of the Indian Ocean Commission, at $<\mathrm{http}$ ://ec.europa.eu/development/body/publications/fish/pe039715.pdf> (accessed 10-6-2017).

Republic of Kenya (2013) Integrated coastal zone management (ICZM) policy.

Republic of Kenya (2014) Kenya vision 2030, at <www.vision2030.go.ke/vision/> (accessed 14-52016).

Ruwa, RK (2006) Coastal and offshore marine fisheries of Kenya: status and opportunities KMFRI Technical Report.

Svensson, LE \& L Pendleton (eds) (2014) Transitioning to a new blue economy: proceedings of the December 2013 economics of the ocean summit Nicholas Institute for Environmental Policy Solution Conference Proceedings.

Tuda, A \& M Omar (2012) "Protection of marine areas in Kenya: the Lenya wildlife service in the 21st century" 29(1) The George Wright Forum 43-50.

UN / United Nations (2010) Resumed review conference on the Agreement Relating to the Conservation and Management of Straddling Fish Stocks and Highly Migratory Fish Stocks, at 
$<$ http://www.un.org/depts/los/convention_agreements/reviewconf/FishStocks_EN_C.pdf $>$ (accessed 25-6-2017).

UN / United Nations (2014) Blue economy concept paper, at <https://sustainabledevelopment.un.org/content/documents/2978BEconcept.pdf> (accessed 14-5-2016).

UNECA / United Nations Economic Commission for Africa (2016) Africa's blue economy: a policy handbook.

UNFAO / United Nations Food and Agricultural Organization (2016) Fishery and aquaculture country profiles: Kenya country profile fact sheets, at $<\mathrm{http} / /$ www.fao.org/fishery/facp/KEN/en> (accessed 20-5-2016).

UNFAO / United Nations Food and Agricultural Organization \& Republic of Kenya (2006) Kenya: national integrated natural resources assessment, at <www.fao.org/forestry/download/1625907d9f8a278081dbc73fa0030fc0182bce.pdf, > (accessed 4-5-2016).

UNFAO / United Nations Food and Agricultural Organization \& Republic of Kenya (2009) Final project report on pilot zones in the coastal, eastern and Lake Victoria regions of Kenya 2007-2008 Draft Three. 